Postgrad. MEd. J., 37, 83

\title{
THE THIRD STAGE OF LABOUR
}

$A$ review of 3,000 consecutive spontaneous deliveries with special reference to the administration of ergometrine and hyalase with the birth of the anterior shoulder.

F. Denny, M.D., M.R.C.O.G.

Consultant Obstetrician and Gynacologist

*A. E. B. MatThews, M.R.C.O.G.

Late Obstetric Registrar

R. M. WILD, R.S.C.N., S.C.M., M.T.D.

Superintendent Midwife

The Department of Obstetrics, St. Mary Abbots Hospital, London, W.8

IN a confidential report on 1,094 maternal deaths between the years 1952 and 1954 , it was shown that hæmorrhage (excluding toxæmic accidental hæmorrhage) constituted the secondlargest clinical group.

Of 188 deaths in this group, 113 were due to:

(a) Post-partum hæmorrhage with retained placenta:

(b) Other post-partum hæmorrhage.

This report serves to emphasize the fact that bleeding after birth of the fotus is still one of the major causes of maternal mortality.

Post-partum hæmorrhage is, by accepted definition, a blood loss of $20 \mathrm{oz}$. or more. The value of such a standard is limited and open to criticism as, in most cases, accurate measurement is impracticable, and the amount of blood lost may bear no relation to the condition of the patient. However, for the purpose of comparison with other writers, this standard has been accepted, but, within the series itself, the amount of blood lost in each case has been recorded, allowing consideration of a wider range of hæmorrhages both greater and less than $20 \mathrm{oz}$.

The use of intravenous ergometrine was first reported in the literature as early as 1935 (Adair, Kharasch and Legault). Sporadic reports, mainly from America, appeared during the intervening years until 1949. During these years the use of oxytocic drugs at the end of the second stage of labour received scant attention and, consequently, scant usage in this country.

Shaw (1949) reported a small series of cases treated by ergometrine or pitocin given intravenously with the crowning of the fotal head. He

*Present Address: West Middlesex Hospital, Isleworth. showed a marked reduction in the duration of the third stage, in blood loss, and the number of blood transfusions required, with no appreciable difference in the incidence of manual removal of the placenta in either the treated or the control groups.

Lister (1950), reporting a larger series, emphasized that if the same staff dealt with the same type of patient under constant conditions, the use of oxytocic drugs at the end of the second stage of labour effected a considerable reduction in blood loss during and after delivery of the placenta. In this series, the post-partum hæmorrhage rate was reduced from $16 \%$ in the control group to $0.4 \%$ in the ergometrine group. There was no increase in the incidence of manual removal of the placenta.

Daley (I95I) published a control series of approximately 500 cases - using intramuscular ergometrine with the crowning of the head. In the control group the post-partum hæmorrhage rate was $15.7 \%$ whereas in the treated group it was reduced to $9.2 \%$.

In a recent personal communication, the same author states that routine use of ergometrine and hyalase with the crowning of the head has reduced the post-partum hæmorrhage rate from $6.4 \%$ in 1955 to $3.1 \%$ in 1957 .

In these series, each writer has questioned the possibility of a contraction ring dystocia. However, they were unable to show any increase in their treated groups.

In a series of 1,000 cases treated by intravenous ergometrine given with the birth of the anterior shoulder, Martin and Dumoulin (1933) achieved a post-partum hæmorrhage rate of $1.2 \%$ as compared with $13.1 \%$ in the control group. However, the 'Manual Removal Rate' was raised to $3 \%$ compared with $1.1 \%$ in the control group. 
In 1954, interest in the use of the intramuscular route was revived by Kimbell, who reported his technique of combining hyaluronidase with ergometrine to increase its speed of action. In his control group, the post-partum hæmorrhage rate was $6.4 \%$, whereas in the treated group it was $3.5 \%$. More recently (1958) the same author has claimed a further improvement in his figures by combining the use of ergometrine and hyaluronidase with the Brandt-Andrews method of delivering the placenta.

The most recent series reported has been that of Dutton (1958). Ergometrine and hyaluronidase were given intramuscularly with the birth of the anterior shoulder to 500 selected patients, and the results compared with 700 controls. He found that the incidence of retained placenta, requiring manual removal, was not significantly increased, whereas the incidence of post-partum hæmorrhage was reduced in the primigravidæ but not so in normal multigravidæ. It must be noted, however, that the treated cases were selected and the control group delivered in another unit of the same hospital.

The year following the publication of Kimbell's work one of us (F.D.) noted in another hospital that, following the employment of ergometrine and hyaluronidase at the end of the second stage of labour as a routine, there was a sharp fall in the post-partum hæmorrhage rate. All suitable cases were treated in this manner for several months, and then the practice was stopped and the hæmorrhage rate immediately increased again. Once more it was effectively reduced by the re-introduction of this prophylactic treatment.

\section{The Present Trial}

In the same year (1955) it was decided to carry out a large trial at St. Mary Abbots Hospital. In this series hyalase (Bengers) has been used and will be referred to by this name throughout the report.

In the maternity department of this hospital all the cases admitted come under the care of the same junior medical and nursing staff. Undergraduate students attend the practice of this department and it is also a Part I training school for midwives. There are two consultants and cases are admitted in approximately equal numbers under one or the other. No attempt at selection of cases is made and random sampling reveals approximately the same geographical and social distribution.

It was agreed, therefore, to use cases under the care of one consultant (A.F.) as the control group. Cases in the other group would be given intramuscular ergometrine $0.5 \mathrm{mg}$. and hyalase $\mathrm{I}, 500$
Benger units ( $1.5 \mathrm{mg}$.) with the birth of the anterior shoulder.

It is possibly more effective when given with the crowning of the head. However, it was consideret wiser to delay treatment until birth of the anterio shoulder, in order to assess its safety as a routine method for the use of midwives.

In this report, 3,000 consecutive norma deliveries have been considered, occurring betwee the years 1955 and 1957 .

Before considering these figures, it seems necesi sary to analyse the reasons for so wide a variatio $\vec{B}$ in the post-partum hæmorrhage rate in the control groups of other series.

TABLE I

Post-Partum Hemorrhage Rates in Different Series

\begin{tabular}{|c|c|c|c|}
\hline \multirow{2}{*}{$\cdot$} & \multirow{2}{*}{ Route } & \multicolumn{2}{|c|}{ Percentages } \\
\hline & & $\begin{array}{c}\text { Ergometrine } \\
\text { Treated }\end{array}$ & Control \\
\hline 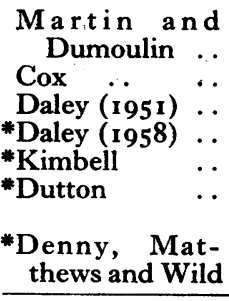 & $\begin{array}{l}\text { I.V. } \\
\text { I.V. } \\
\text { I.M. } \\
\text { I.M. } \\
\text { I.M. } \\
\text { I.M. }\end{array}$ & $\begin{array}{c}\begin{array}{l}1.2 \\
0.3 \\
9.2 \\
3.1\end{array} \\
2.6\left\{\begin{array}{l}3.5 \\
\mathrm{P}_{\mathrm{M}}-2.5 \\
\mathrm{M} .-2.7\end{array}\right. \\
4.35 \\
\end{array}$ & 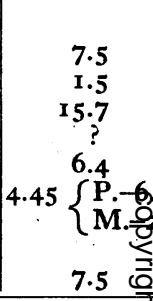 \\
\hline
\end{tabular}

*Ergometrine combined with hyaluronidase.

P. = Primigravidæ. $\quad$ M. = Multigravidæ.

These figures, given in Table $I$, indicate th育 hæmorrhage, or its measurement, varies considerably with the individual unit concerned. In the control groups shown above, the post-partum hæmorrhage rate ranges from $1.5 \%$ (Cox) to $15.7 \%$ (Daley). It would seem that only when conditions are absolutely constant for treated and control cases can any accurate conclusions bo drawn.

The actual quantity of blood lost is probablo not as important as the effect of abnormal bloo loss on the individual patient. The variation is these control figures may be due to several factors some of which have been enumerated below:

I. Accuracy of Measurement. The mixture of liquor, antiseptic solution, and the inevitable absorption by sterile towels make a measurements to the nearest ounce very unlikely to be accurate When $20 \mathrm{oz}$. is stressed as a vital figure, approximas tions will inevitably be below rather than aboves this figure.

2. Variation between Series. Irrespective of the use of oxytocic drugs, the method of management of the third stage shows a wide variation in differen units. It is not surprising, therefore, that results 
will differ. Soon after the commencement of the present trial there appeared to be a reduction in the hæmorrhage rate in the control group. The following figures suggest that this improvement was either temporary or apparent rather than real.

1953-1954. Post-partum hæmorrhage rate $=$ $7.8 \%$.

1955-1957 (control series). Post-partum hæmorrhage rate $=7.5 \%$.

3. Selection of Cases. In each report there has been a slight variation in the selection of cases making them comparable with their controls, but not with other series.

In order to achieve as accurate a comparison as possible in this series, the figure $20 \mathrm{oz}$. was never stressed to the staff, but measurement was divided into groups (see Table 3 ).

A fixed routine was practiced for the management of the third stage, and the labour-ward staff was the same for treated and control groups.

TABLE 2

Distribution of CAses

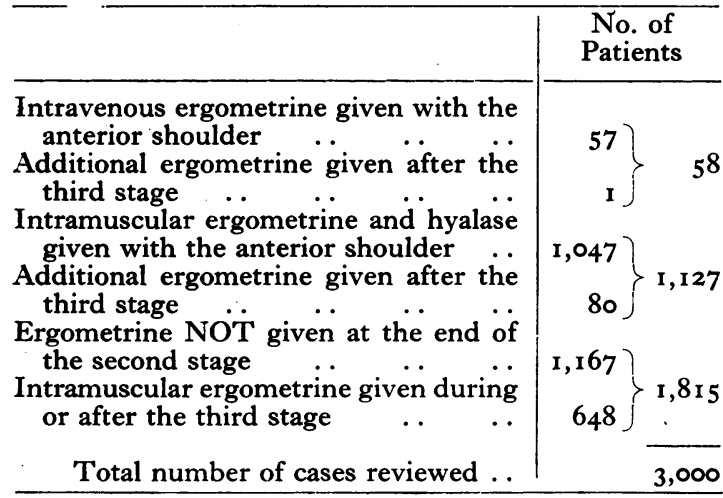

When the review of these cases was commenced it became clear that it was an opportunity to study various aspects of the third stage of labour beyond the simple evaluation of the use of ergometrine and hyalase. The results are given in this report.
It is inevitable that such results must be shown mainly in tabular form.

No attempt has been made to compare primigravidæ with multigravidæ throughout the review. This has been confined to a separate study, the results of which are shown in Tables roa and Iob.

The effect of anæmia on the incidence of postpartum hæmorrhage is of considerable importance and has been stressed in the Report on Maternal Deaths 1952 to 1954. We have considered it regrettable but necessary to discard these figures. All patients have routine blood tests including a hæmoglobin estimation carried out at the booking clinic. Thereafter a further hæmoglobin estimation is performed at or about the $34^{\text {th }}$ week of pregnancy. These two values do not necessarily indicate the presence of an anæmia at the onset of labour.

In order to assess the importance of anæmia in relation to post-partum hæmorrhage, a hæmoglobin estimation is being performed at the onset of labour. It is hoped to analyse these results in a later report.

\section{Results \\ Blood Loss}

A comparison was made between blood loss in the ergometrine-hyalase-treated group and the

TABLE 4

Comparison of Post-Partum Hamorrhage in THe Treated and Control Groups

\begin{tabular}{|c|c|c|c|}
\hline & \multicolumn{3}{|c|}{ Number of Patients } \\
\hline & $\begin{array}{c}\text { With } \\
\text { P.P.H. }\end{array}$ & $\begin{array}{l}\text { Without } \\
\text { P.P.H. }\end{array}$ & Totals \\
\hline Control group. . & $\begin{array}{c}136 \\
(7.49 \%)\end{array}$ & 1,679 & I,815 \\
\hline Treated group & $\begin{array}{c}49 \\
(4.35 \%)\end{array}$ & $\mathrm{I}, 078$ & I, 127 \\
\hline Totals .. & 185 & 2,757 & 2,942 \\
\hline
\end{tabular}

$x^{2}=11.14 ; \mathrm{n}=1 ; \mathrm{p}<0.001$.

TABLE 3

Comparison of Blood Loss in Ergometrine-Hyalase-Treated Group and Controls

\begin{tabular}{|c|c|c|c|c|c|c|c|c|c|}
\hline \multicolumn{10}{|c|}{ Numbers of Patients with Blood Loss (in ounces) } \\
\hline & & & & $<5$ & $5^{-10}$ & $10-20$ & $20-40$ & $>40$ & Totals \\
\hline Control group & $\cdots$ & . & . & $\begin{array}{r}726 \\
(40 \%)\end{array}$ & $\begin{array}{c}614 \\
(34.2 \%)\end{array}$ & $\begin{array}{c}339 \\
(13.5 \%)\end{array}$ & $\begin{array}{c}118 \\
(6.3 \%)\end{array}$ & $\begin{array}{c}18 \\
(1.0 \%)\end{array}$ & I,8 15 \\
\hline Treated group & . & . & . & $\begin{array}{c}526 \\
(46.5 \%)\end{array}$ & $\begin{array}{c}410 \\
(36.5 \%)\end{array}$ & $\begin{array}{c}142 \\
(12.6 \%)\end{array}$ & $\begin{array}{c}43 \\
(3.8 \%)\end{array}$ & 6 & I, 127 \\
\hline Totals & . & . & . & 1,252 & 1,024 & 481 & $16 r$ & 24 & 2,942 \\
\hline
\end{tabular}

$\varkappa^{2}=41.36 ; \mathrm{n}=4 ; \mathrm{p}<0.001$. 
controls. The results are shown in Table 3. It will be seen that $77 \%$ of patients of both groups had a blood loss of less than $20 \mathrm{oz} .: 16.3 \%$ had a loss of between 10 and $20 \mathrm{oz}$.

Hæmorrhage in the treated group was reduced, and the difference between the two groups is highly significant. It could be expected by chance in less than one in a thousand similar trials.

Primigravidæ and multigravidæ being considered together, the incidence of post-partum hæmorrhage in the treated and control groups was $4.35 \%$ and $7.5 \%$ respectively.

TABLE 5

The Incidence of Manual Removal of the Placenta

\begin{tabular}{|c|c|c|c|c|}
\hline & & & $\begin{array}{l}\text { Manual } \\
\text { Removal }\end{array}$ & Totals \\
\hline Control group & . & . & $\begin{array}{c}15 \\
(0.8 \%)\end{array}$ & 1,167 \\
\hline Treated group & . & . & $\begin{array}{c}17 \\
(1.5 \%)\end{array}$ & 1,047 \\
\hline Totals & .. & .. & 32 & 2,214 \\
\hline
\end{tabular}

These numbers suggest that the 'Manual Removal Rate' is higher in the treated group of cases. This impression supports the views of many obstetricians who have used ergometrine as a routine in the third stage. However, comparison cannot be made with other series, as the management of the third stage varies slightly in most units.

\section{TABLe 6}

Comparison of Blood loss in Relation to the Length of the First Stage of Labour

\begin{tabular}{|c|c|c|c|c|}
\hline \multirow{2}{*}{$\stackrel{(a)}{\text { Control Group }}$} & \multicolumn{3}{|c|}{ Blood Loss in Ounces } & \multirow{2}{*}{ Totals } \\
\hline & $<5$ & $5^{-10}$ & $>10$ & \\
\hline $\begin{array}{l}\text { First stage less } \\
\text { than } 24 \text { hours }\end{array}$ & $\begin{array}{c}672 \\
(40 \%)\end{array}$ & $\begin{array}{c}575 \\
(34.2 \%)\end{array}$ & $\begin{array}{c}429 \\
(25.8 \%)\end{array}$ & 1,676 \\
\hline $\begin{array}{l}\text { First stage longer } \\
\text { than } 24 \text { hours }\end{array}$ & $\begin{array}{c}54 \\
(38.9 \%)\end{array}$ & $\begin{array}{c}39 \\
(27.8 \%)\end{array}$ & $\begin{array}{c}46 \\
(33.3 \%)\end{array}$ & I3 \\
\hline Totals .. & 726 & 614 & 475 & I, 8I 5 \\
\hline
\end{tabular}

$x^{2}=4.29 ; \mathrm{n}=2 ; 0.2>\mathrm{p}>0.1$.

\begin{tabular}{|c|c|c|c|c|}
\hline \multirow{2}{*}{$\begin{array}{c}(b) \\
\text { Treated Group }\end{array}$} & \multicolumn{3}{|c|}{ Blood Loss in Ounces } & \multirow{2}{*}{ Totals } \\
\hline & $<5$ & $5-10$ & $>10$ & \\
\hline $\begin{array}{l}\text { First stage less } \\
\text { than } 24 \text { hours }\end{array}$ & $\begin{array}{c}487 \\
(46.4 \%)\end{array}$ & $\begin{array}{c}383 \\
(36.5 \%)\end{array}$ & $\begin{array}{c}175 \\
(17.1 \%)\end{array}$ & 1,045 \\
\hline $\begin{array}{l}\text { First stage longer } \\
\text { than } 24 \text { hours }\end{array}$ & $(48.8 \%)$ & $\begin{array}{c}27 \\
(33.8 \%)\end{array}$ & $\begin{array}{c}16 \\
(17.4 \%)\end{array}$ & 82 \\
\hline otals ... & 526 & 410 & 191 & I , 127 \\
\hline
\end{tabular}

$x^{2}=0.64 ; \mathrm{n}=2 ; \mathrm{p}>0.7$.
During the period that this report covers, expulsion, expression and cord traction were not allowed under any circumstances. A manua removal was performed in all cases where bleeding. accompanied a retained placenta. In the absence of hæmorrhage, the placenta was removed after one hour.

No case of contraction ring was encountere承 during these operations, either in the treated or the control group.

The controls with a longer first stage had a little more blood loss, but the difference, althoug suggestive, is not significant at the $5 \%$ levei. Alternatively, it may be stated that there was afy indication that, in the control group, a longer first stage may be associated with more blood loss More definite conclusions could only be drawn 语 a bigger trial was carried out.

In those given ergometrine and hyalase the blood loss was independent of the first stage of labour.

TABLE 7

Comparison of Blood loss in Cases with a Firs $\overrightarrow{\mathrm{T}}$ Stage of Over 24 Hours

\begin{tabular}{|c|c|c|c|c|}
\hline & \multicolumn{3}{|c|}{ Blood Loss in Ounces } & \multirow{2}{*}{ Tota然 } \\
\hline & $<5$ & $5^{-10}$ & $>10$ & \\
\hline Control group & $\begin{array}{c}54 \\
(38.6 \%)\end{array}$ & $\begin{array}{c}39 \\
(27.9 \%)\end{array}$ & $\begin{array}{c}46 \\
(33.5 \%)\end{array}$ & $\frac{\pi}{2}$ \\
\hline Treated group & $(48.8 \%)$ & $\begin{array}{c}27 \\
(33.8 \%\end{array}$ & $\begin{array}{c}16 \\
(17.4 \%)\end{array}$ & \\
\hline Totals & 93 & 66 & 62 & 221 \\
\hline
\end{tabular}

$\varkappa^{2}=4.13 ; \mathrm{n}=2 ; 0.2>\mathrm{p}>0.1$.

The treated group of cases with a first stage greater than 24 hours had less hæmorrhage, but the difference, although suggestive, is not significant at the $5 \%$ level. It could be argued that these conclusions are open to doubt on the grounds that there could have been a higher incidence of cases. with a prolonged first stage of labour in one of other of the groups. It was, therefore, decided to compare the two sets of figures separately:

TABLE 8

Length of the First Stage of Labour

\begin{tabular}{|c|c|c|c|}
\hline & $<24$ hrs. & $>24 \mathrm{hrs}$. & Totals \\
\hline Control group.. & 1,676 & $\begin{array}{c}139 \\
(7.65 \%)\end{array}$ & 1,815 \\
\hline Treated group & I, 045 & $\begin{array}{c}82 \\
(7.27 \%)\end{array}$ & $\mathbf{I}, 127$ \\
\hline Totals .. & 2,721 & 22 I & 2,942 \\
\hline
\end{tabular}

Thus 82 out of 1,127 , i.e. $7.27 \%$ of the treated 
and 139 out of 1,815 , i.e. $7.65 \%$ of the controls had a first stage of over 24 hours.

From this it can be seen that there was no significant difference in the duration of the first stage of labour in the two groups.

\section{The Duration of the Third Stage of Labour}

Since the rationale of this method of treatment is based upon the conception and knowledge that in most cases the placenta separates almost at once, the length of the third stage in treated cases should be shorter. No attempt has been made in this series to time the duration of the third stages to the nearest minute but rather more loosely to group them under two headings:

(a) Less than 15 minutes.

(b) More than 15 minutes.

Study of the longer time groups could not be considered in this series, as the placenta was manually removed after one hour as a routine.

\section{TABLE 9}

Duration of The Third Stage

\begin{tabular}{|c|c|c|c|}
\hline & $<15$ mins. & $>15$ mins. & Totals \\
\hline Control group & $\begin{array}{c}1,182 \\
(65.5 \%)\end{array}$ & $\begin{array}{c}633 \\
(34.5 \%)\end{array}$ & 2,942 \\
\hline Treated group & $\begin{array}{c}901 \\
(80.1 \%)\end{array}$ & $\begin{array}{c}226 \\
(19.9 \%)\end{array}$ & I, 127 \\
\hline Totals & 2,083 & 859 & 2,942 \\
\hline
\end{tabular}

$x^{2}=90.6 ; \mathrm{n}=2 ; \mathrm{p}<0.001$.

This indicates that a statistically significant number of cases had shorter third stages in the group treated with ergometrine and hyalase.

Table 10

Relation of Parity to Post-Partum Hamorrhage RATE

\begin{tabular}{|c|c|c|c|c|}
\hline \multirow{2}{*}{$\begin{array}{c}(a) \\
\text { Control } \\
\text { Group }\end{array}$} & \multicolumn{3}{|c|}{ Parity } & \multirow{2}{*}{ Totals } \\
\hline & I & $2-4$ & $>_{4}$ & \\
\hline P.P.H. & $\begin{array}{c}78 \\
(8.5 \%)\end{array}$ & $\begin{array}{c}47 \\
(5.7 \%)\end{array}$ & $\begin{array}{c}\text { I I } \\
(13.4 \%)\end{array}$ & 136 \\
\hline No. P.P.H. & 840 & 768 & 71 & 1,679 \\
\hline Totals & 918 & 815 & 82 & 1,815 \\
\hline
\end{tabular}

$x^{2}=8.99 ; \mathrm{n}=2 ; \mathrm{p}<0.002$.

\begin{tabular}{|c|c|c|c|c|}
\hline \multirow{2}{*}{$\begin{array}{c}(b) \\
\text { Treated } \\
\text { Group }\end{array}$} & \multicolumn{3}{|c|}{ Parity } & \multirow{2}{*}{ Totals } \\
\hline & $\mathbf{I}$ & $2-4$ & $>_{4}$ & \\
\hline P.P.H. & $\begin{array}{c}24 \\
(4.4 \%)\end{array}$ & $\begin{array}{c}20 \\
(3.8 \%)\end{array}$ & $(8.4 \%)$ & 49 \\
\hline No. P.P.H. & 517 & 507 & 54 & 1,078 \\
\hline Totals & $54 \mathrm{I}$ & 527 & 59 & I, I 27 \\
\hline
\end{tabular}

In the control group the incidence of postpartum hæmorrhage was greatest in those with parity greater than four. The difference is significant at the $5 \%$ (but not $1 \%$ ) level. It can be seen that danger of a post-partum hæmorrhage is greater in primigravidæ than in those with parity from two to four $(8.5 \%$ compared with $5.7 \%)$, but after the fourth pregnancy this danger increases markedly ( $13.4 \%)$.

The number of cases with post-partum hæmorrhage in the treated group was too few to be statistically tested. The pattern remains the same, however, those with parity of two to four being a slightly lesss risk than primigravidæ while those with parity greater than four are twice as likely to suffer from excess hæmorrhage.

\section{The Relation of Blood Loss to Age}

As age increases among primigravidæ the necessity for operative intervention becomes more frequent. It might be expected that increased blood loss would be a further hazard for the

TABle I I

Age AND Blood Loss

\begin{tabular}{c|c|c|c|c|c|}
\hline $\begin{array}{c}(a) \\
\text { Control Group }\end{array}$ & \multicolumn{2}{|c|}{ Blood Loss in Ounces } & \\
\hline Age in Years & $<5$ & $5^{-10}$ & $10-20$ & $>_{20}$ & Totals \\
\hline$<25$ & 307 & 255 & 155 & 67 & 784 \\
\hline $25-35$ & 348 & 295 & 158 & 65 & 866 \\
\hline$>35$ & 71 & 64 & 26 & 4 & 165 \\
\hline Totals & 726 & 614 & 339 & 136 & 1,815 \\
\hline
\end{tabular}

(b)

\begin{tabular}{c|c|c|c|c|c}
\hline Treated Group & \multicolumn{3}{|c|}{ Blood Loss in Ounces } & \\
\hline Age in Years & $<5$ & $5-10$ & $10-20$ & $>20$ & Totals \\
\hline$<25$ & 232 & 159 & 61 & 14 & 466 \\
\hline $25-35$ & 255 & 214 & 63 & 32 & 564 \\
\hline$>35$ & 39 & 37 & 18 & 3 & 97 \\
\hline Totals & 526 & 410 & 142 & 49 & 1,127 \\
\hline
\end{tabular}

\begin{tabular}{|c|c|c|c|c|c|}
\hline (c) All Cases & \multicolumn{4}{|c|}{ Blood Loss in Ounces } & \\
\hline Age in Years & $<5$ & $5-10$ & $10-20$ & $>\mathbf{2 0}$ & Totals \\
\hline$<25$ & 539 & 414 & 216 & $8 r$ & 1,250 \\
\hline $25-35$ & 603 & $5 \circ 9$ & 221 & 97 & 1,430 \\
\hline$>35$ & I 10 & IOI & 44 & 7 & 262 \\
\hline Totals & 1,252 & 1,024 & $48 I$ & 185 & 2,942 \\
\hline
\end{tabular}


elderly primigravida. That this is not the case is shown in the following three tables in which the treated and control groups are considered separately and then the total cases together.

Analysis of the numbers of patients in Table I IC shows that there is no significant difference in blood loss in the three age groups. Similarly, analysis of the treated and control groups also reveals no significant difference.

\section{Conclusions}

It seems reasonable to conclude from all these results that:

I. The administration of ergometrine and hyalase:

(a) Reduces blood loss and the incidence of post-partum hæmorrhage.

(b) Reduces the duration of the third stage of labour.

(c) Makes blood loss independent of the length of the first stage of labour.

2. Blood loss varies little if at all with age.

3. In both treated and untreated cases, blood loss and the incidence of post-partum hæmorrhage are greatest in multiparæ with more than four children. The incidence in primigravidæ is greater than in multiparæ with one to four children.

4. The incidence of manual removal of the placenta is increased in those given ergometrine and hyalase.

5. There does not appear to be any increased danger from contraction ring dystocia when ergometrine has been administered at the end of the second stage.
Finally we consider that this is a safe method routine prophylactic treatment for use by mid wives, its advantages being now well established.\$

\section{Summary}

A study of the third stage of labour of 3,000 consecutive, spontaneous deliveries has been made with special reference to the administration of ergometrine combined with hyaluronidase given by the intramuscular route. Particular attentio $\$$ has been paid to such features as the length of the third stage in each group, the effect of prolonged labour on post-partum hæmorrhage, also the effect of parity and age on blood loss in both treated and untreated groups.

\section{Acknowledgments}

We wish to thank Miss Amy M. Fleming forit permission to use those cases under her care as our control series. We also thank the juniofs medical and nursing staff for their ready co-operæo tion in this trial. We are grateful to Dr. Brian Lacey of Westminster Hospital Medical School for the statistical analysis of these figures and for his advice and interest.

Mr. L. Woodrow Cox, Mr. N. Kimbell, Me J. G. Dumoulin and Miss Doreen Daley we wis. also to thank for their interest and permission to quote their published figures.

We also acknowledge the permission of the Editors of The Fournal of Obstetrics and Gyncecolgo of the British Empire, The Lancet, The Britis Medical Fournal and the New Zealand Medico, fournal to publish the figures of the above authors

\section{REFERENCES}

Adair, F. L., Davis, M. E., Karasch, M. S., and Legault, R. R. (1935): Study of a New and Potent Ergot Derivative Ergotocin, Amer. F. Obstet. Gynec., 30, 466.

Cox, L. W. (1954): Ergometrine and the Third Stage of Labour, N.Z. med. F., 53, 380.

DALEY, D. (195I): Use of Ergometrine at the end of the Second Stage of Normal Labour, F. Obstet. Gynac. Brif Emp., 58, 388 .

Daley, D. (1958): Personal communication.

Dutron, W. A. W. (1958): Use of Ergometrine with Hyaluronidase to Prevent Postpartum Hæmorrhage, $\mathscr{f}$. Obstę Gynac. Brit. Emp., 65, 315.

KIMBELl, N. (1954): Intramuscular Ergometrine and Hyaluronidase in Prevention of Postpartum Hæmorrhage used by Midwives in 2,002 Cases, Brit. med. $\mathcal{F}$., ii, 130 .

Kimbell, N. (1958): Brandt-Andrews Technique of Delivery of the Placenta, Ibid., ii, 203. LISTER, U. M. (I950): Use of Intravenous Oxytocics in the Second Stage of Labour, F. Obstet. Gynac. Brit. Empg
57, 210. MarTiN, J. D., and Dumoulin, J. G. (1953): The Use of Intravenous Ergometrine to Prevent Postpartum Hæmorrhagß్ర్
Brit. med. F., i, 643.

Report on Confidential Enquiries into Maternal Deaths in England and Wales, 1952-1954 (1957). Ministry of Healt Publication No. 97. H.M.S.O.

Shaw, D. A. F. (1949): Oxytocic Drugs in the Third Stage of Labour, F. Obstet. Gynac. Brit. Emp., 56, 833. 
Miller, A. A. and Jackson, F. B. (1954): Gross Arterial Embolism by a Myxosarcoma of Pulmonary Origin, $\mathcal{~}$. Path. Bact., 68, $22 \mathrm{I}$.

MoRrell, R. M. (1958): Cranial Neuropathy in Advanced Hodgkin's Disease, Dis. nerv. Syst., 19, 26r.

Oelbaum, M. H. and Strich, Sabina J. (I953): Thrombophlebitis Migrans and Carcinoma of the Body and Tail of Pancreas, Brit. med. $\mathcal{Y}$., ii, 907.

Savage, C. and Noble, D. (1954): Cancer of the Pancreas: Two Cases Simulating Psychogenic Illness, F. nerv. ment. Dis., 120, 62.

Selinsky, H. (1930): Metastatic Carcinoma of the Brain and Cord Simulating Polyneuritis, Arch. Neurol. Psychiat. (Chicago), 23, 197.

ShaFAR, J. (1954): Bronchial Neoplasm with Myasthenia, Lancet, i, rog.

SMITH, J. P. and YATES, P. O. (1955): The Thrombotic Syndrome Associated with Carcinoma, f. Path. Bact., 70, i 1 I.

SMITH, W. T. and WHITfield, A. G. W. (1954): Intravascular Microembolic Carcinomatosis as a Cause of Purpura. Report of a Case associated with Focal Histological Lesions in the Nervous System, Brit. F. Cancer, 8, 97.

(1955): Malignant Sensory Neuropathy, Lancet, i, 282.

- (1957): Studies on the Association of Carcinoma and Neuropathy which is not Attributable to Neural Metastases, M.D. Thesis. University of Birmingham.

Sparling, H. J. JR., AdAMS, R. D., and PARKer, F. (1947): Involvement of the Nervous System by Malignant Lymphoma, Medicine, 26, 285.

Sproul, E. E. (1938): Carcinoma and Venous Thrombosis: The Frequency of Association of Carcinoma in the Body or Tail of the Pancreas and Multiple Venous Thromboses, Amer. F. Cancer, 34, 566.

Storjohan, K. R. (1932): Cited by Madow, L. and Alpers, B. J. (1952), see above, Frankfurt. Z. Path., 43, 80.

Thompson, T. and Evans, W. (1929-30): Paradoxical Embolism, Quart. Y. Med., 23, 135.

Trousseau, A. (1873): Clinique médicale de l'Hôtel-Dieu de Paris, 3, 695. 4th edition. Paris: Baillière.

Victor, M., BANKer, BetTy Q., and Adams, R. D. (1958): The Neuropathy of Multiple Myeloma, $\mathcal{F}$. Neurol. Neurosurg. Psychiat., 21, 73 .

- AdAMS, R. D., and Mancall, E. L. (1959): A Restricted Form of Cerebellar Cortical Degeneration Occurring in Alcoholic Patients, Arch. Neurol. (Chicago), I, 579.

Walton, J. N. and Adams, R. D. (1958): Polymyositis. ist edition. Edinburgh: E. \& S. Livingstone.

Williams, A. A. (1954): Malignant Disease Associated with Vascular Phenomena, Brit. med. F., ii, 82.

Williams, H. M., Diamond, H. D., and Craver, L. F. (1958): The Pathogenesis and Management of Neurological Complications in Patients with Malignant Lymphomas and Leukæmia, Cancer, Ir, 76.

Willis, R. A. (1952): The Spread of Tumours in the Human Body. 2nd edition. London: Butterworth.

\section{ERRATUM}

' THE THiRd Stage Of LABOUR', by F. Denny, A. E. B. Matthews, and R. M. Wild February issue 196r. Page 86, Table 5:

Page 87, Table 9:

Column giving totals-for 1,167 read 1,815 ; for 1,047 read 1,127; for 2,214 read 2,942.

Total of control group-for 2,942 read I,8 5 . 